\title{
A Textbook Evaluation of Speech Acts: The Case of English Result Series
}

\author{
Minoo Alemi (Corresponding author) \\ Languages and Linguistics Department, Sharif University of Technology \\ Azadi Street, Tehran, Iran \\ E-mail: alemi@sharif.ir \\ Roja Irandoost \\ Languages and Linguistics Department, Sharif University of Technology \\ Azadi Street, Tehran, Iran \\ E-mail: roja.irandoost@yahoo.com
}

Received: 20-07- 2012

Accepted: 17-08- 2012

Published: 01-11- 2012

doi:10.7575/ijalel.v.1n.6p.199

URL: http://dx.doi.org/10.7575/ijalel.v.1n.6p.199

\begin{abstract}
The present work aimed to investigate the frequency of occurrences and proportions of speech acts of complaints and compliments in the four volumes of the course book English Result (Elementary, Pre-intermediate, Intermediate, and Upper-intermediate), by Mark Hancock and Annie McDonald (2009), published by Oxford University Press. Investigation of the two speech act strategies was based on complaints strategies (Olshtain and Weinbach, 1987) and compliment strategies (Wolfson and Manes, 1981). It was found that the books were rich in terms of the number of the two speech acts, but in presenting them, there were one or two dominant strategies in both cases. Chi-square analysis demonstrated that there was a significant difference in the proportion of complaint and compliment strategies through the four course books. In general, the books were reported to provide learners with adequate amount of complaints and compliments, but with low variations in strategy types, which may result in learners not having sufficient conceptual and practical knowledge of speech acts to use them appropriately in different contexts. Based on the findings of this study, it seems necessary to incorporate more authentic and helpful instruction of speech acts along with the course books, to improve the learners' performance in real life communication.
\end{abstract}

Keywords: Course book evaluation, Speech acts, speech acts strategies, Complaints, Compliments

\section{Introduction}

All people live in social groups which need to maintain a certain degree of harmony (Wouk, 2006). Speech acts are the social functions of language. Everything we do with words when we speak is called speech acts (Austin, 1962). We use speech acts to perform actions. Some different types of speech acts in English include apology, invitation, complaint and compliment. The ability to understand and produce speech acts of a given language is called communicative competence (Bella, 2011). As Wouk (2006) states, as long as speech acts are of the social aspects of language, and as long as societies differ in their social organizations, there is also variation in the way these social acts are carried out.

One important concept in performing appropriate speech act strategies is politeness, which is considered a prior need for adequate communicative/sociopragmatic competence. Therefore, many studies in this area have been theoretically based on several different politeness models. Wierzbicka (1991) defines politeness, as a person's effort to respect other's right, autonomy and privacy. Politeness strategies, according to her, are context specific and may vary drastically from one culture to another.

Having borrowed "face", they define it as something that is emotionally invested, and that can be lost, maintained or enhanced, and must be constantly attended to in interaction. Face has also been defined by Brown and Levinson (1987) as the social self-image that every member of a society tends to own and manifest for himself. At the center of all politeness models is the notion of indirectness. This notion is of high importance in speech acts, because it determines to what extent communication may end in failure or success. 
Compliments are face-saving speech acts usually performed in order to show approval of some possession of the addressee which could be a kind of behavior, or properties of the addressee. In Brown and Levinson's (1987) term, paying a compliment is a positive politeness strategy that addresses the hearer's positive face.

Regarding complaints, scholars define it as not a single utterance but a combination of several utterances taken together. Performance of complaint may be accompanied by criticism. The goal in this act is not necessarily trying to compensate for something, but is rather to show despair about something that went wrong or sort of an unacceptable behavior.

Researchers have controverted the correlation between implicitness and politeness and between explicitness and impoliteness (Meier, 1995, 1997; Weizman, 1989). A study done by House and Kasper (1981) revealed that English speakers use more indirect utterances than Germans do in complaints and requests, an issue which results from different socio-cultural factors (Chen, 2003). That is maybe the reason why English people usually think of Germans as being rather impolite.

Therefore, according to the historical experiments (Stadler 2011), the general view is that the more indirect the complaint (or more generally the speech act), the less impolite it is to the addressee, or the more implicit the utterance, the more polite it will be, although there are still some few studies that show it's not always the case.

Regarding second and foreign language settings, along with teachers, textbooks have always been thought of as the main sources of input for the learners. As a result, there has been a crucial need for the textbooks and course books to be appropriately designed in order to provide learners adequately with what they need to learn. That is why it is also essential to evaluate the books in terms of their sufficient coverage of the intended materials.

Textbook evaluation is an applied linguistic process through which teachers, materials developers, etc can "make judgments about the effect of the materials on the people using them" (Tomlinson, et al, 2001, p.15 cited in Azizifar, et al, 2010). McGrath (2002) thinks that textbook evaluation is of an important value for the development and administration of language learning programs (McGrath, 2002 cited in Azizfar, et al, 2010).

Generally, all textbooks are usually thought to easily cover linguistic aspects of a language, but when it comes to language use, not all of them may operate efficiently. That is perhaps due to incorporating inadequate materials in terms of the communicative aspect of language, at the center of which is pragmatics.

As a result, investigating textbooks to find out whether they include the required pragmatic issues, specifically speech acts, seems vital in the field of L2. Two very important speech acts are complaints and compliments. Strategies used to perform speech acts are highly dependent on the culture of the associated country or region. Complaints, as negative speech acts, and especially compliments, as positive ones, vary largely among different cultures.

In order to perform speech acts, the speaker is supposed to take speech act strategies. Olshtain and Weinbach listed seven complaint strategies in 1987, which are mentioned in section 3.1. Wolfson and Manes (1980) categorized compliments into three major syntactic patterns, which are mentioned in section 3.1, with some other structures added to those three as they were found in other studies (However, these researchers have combined the two first structures when analyzing the data). Thus, it is apparently worth studying to find out if learners are exposed to enough input on the part of their course books to let them gain knowledge of pragmatics, and practically apply them in real life.

The focus of this study is to analyze and evaluate the frequency of compliments and complaints in English Result Series (Hancock and McDonald, 2009), which are relatively new course books in the market, and also to add data to the growing literature of speech acts, regarding compliments and complaints. However, due to the lack of presence of dialogues in the last two levels of this series, intermediate and upper-intermediate, the researchers decided to probe only the listening parts of the books in terms of the number of complaints and compliments.

The present study seeks to answer the following questions:

1. What is the frequency of occurrences of compliments and complaints in the four course books of this study?

2. Is there any statistically significant difference in the proportion of the two speech acts identified in this study?

\section{Literature Review}

Until almost 30 years ago, in EFL (English as a Foreign Language) context, the focus was mostly and somewhat only on linguistic competence; in 1980 however, Canale and Swain proposed the notion of communicative 
competence. Later, Bachman completed this in 1990, by adding 'pragmatic competence' and stating it as the primary element of communicative competence which needed to be taught along with that. So knowledge of intercultural communication is a major issue to be taken into account.

As Delen and Tavil (2010) mention, even if somebody can make grammatically right sentences, does not mean that $\mathrm{s} /$ he is also good at making pragmatically appropriate sentences. Speech acts as the central notion of pragmatics have undergone several studies, most of which are based on the politeness model. Indirect speech has often been considered to be the polite way of speaking. This is because the indirect way is more face-saving, less confrontational and thus less aggressive.

There are various factors influencing EFL learners' production of pragmatically good utterances, one of which is the amount of input. As a result, course books and textbooks, as "the visible heart of any ELT program" (Kırkgöz, 2009) have been investigated in various studies, and - despite their importance as the basis for a large part of the language input learners are exposed to in the classroom (O'Neill, 1982)- have been found not to include all the necessary input, at least in terms of authenticity and coverage of important aspects of speech acts (Bouton, 1996; Salazar Campillo, 2007; Uso-Juan, 2007; Vellenga, 2004).

In a study done by Delen and Tavil (2010), which investigated the frequencies of three speech acts of refusals, requests and complaints in course books, it was demonstrated that complaints- despite being so important- were almost ignored in all of the course books being probed, including Top Notch, Summit, Northstar Listening and Speaking and Northstar Reading and Writing Series. It was concluded from the very low and almost zero frequency of this speech act in the books, and thus was considered as the shortcoming of these course books not to provide their learners with adequate complaint strategies which were in correlation with the students' responses in their DCTs completion. However, one point in this research is that the researchers studied only the intermediate level, and this could be mentioned as a limitation to this work. The researchers might have thought that the results could be generalized to other levels as well, but this is not always the case.

Despite the enormous studies done on the field of speech acts, the majority of them have focused on refusals, apologies, requests, face, and the strategies taken to perform these speech acts. Fewer studies have investigated complaints and compliments.

Most people would believe that logically an indirect complaint would always be more polite, and thus would agree on the tight relationship between indirectness and politeness. Blum-Kulka (1987) demonstrated that the most polite strategies in English and Hebrew are practically the indirect ones. In the meantime, indirect strategies are said to be unclear and vague to the addressee sometimes, and may not always result in what the speaker wishes to achieve (Stadler 2011). Implicit strategies, or in other words indirect strategies, are often considered to be used when the speaker intends to be direct to some extent, and at the same time, tries to avoid offending the addressee by showing concern for their face (Stadler 2011), or as Boxer (1993) states when the complainee is not responsible for the offence. However some studies revealed that this is not always the case and such relations do not always hold true. According to Brown and Levinson's (1987) face theory, it is exactly the opposite, meaning that if the complaint is more direct, the complainant will try to use a more compensating language. They reported that not all indirect forms are considered polite in all contexts, a claim which is similar to the case studied by Wierzbicka in 1985, in which she states that being direct is not necessarily being impolite in Polish. So, in sum, face is probably the main element to be taken into account regarding complaints, and compliments as well. These writers would also agree with the issue of face, but would not totally be on the part to say that one strategy or speech act is purely im/polite in any given context or situation.

Olshtain (1989) found that "at a global level of analysis, we can identify universal manifestations of strategy selection" (Olshtain, 1989 cited in Wouk 2006, p. 1458). Research has shown cross-cultural differences in the frequencies of various strategies (Ang-Abbey, 1991 cited in Wouk 2006; Garcia, 1989; Lipson, 1994; Meier, 1996) and also in the details of the language used (Cordella, 1990, 1991; Suszczynska, 1999). Therefore, as mentioned earlier, if the pragmatic issues are not taken into adequate consideration, there will be serious consequences resulting from misunderstandings, as in the case of German Learners of English studied by House and Kasper in 1981. After investigating the directness levels of German and English speakers in their study, they realized that German learners of English were considered as being rather impolite, because it sounded that these learners used more direct complaints and requests compared to English speakers.

\section{Methodology}

\subsection{Materials and Instruments}


The materials under this study were the English Result Series, student books (all of the listening exercises in the books, specifically), written by Mark Hancock and Annie McDonald, published by Oxford University Press in 2009. The series are being taught in some English institutes in Iran. All four levels of Elementary (E), Pre-intermediate (PI), Intermediate (IN) and Upper-intermediate (UI) of these series were investigated. The instrumentations were the set of complaint strategies presented by Olshtain and Weinbach (1987):

1. Below the level of reproach

2. Expression of annoyance or disapproval

3. Accusation and warning

4. Requests for repair

5. Justification

6. criticism

and the set of compliment structures presented by Wolfson and Manes (1980):

1. NP looks/is (intensifier) ADJ.

2. PRO is (intensifier) (a) ADJ NP.

3. I intensifier like/love NP.

4. You V. (a) (really) ADJ. NP.

5. You V. NP. (really) ADV.

6. You have (a) (really) ADJ. NP.

7. What (a) ADJ. NP!

8. ADJ. NP!

9. Isn't NP. ADJ!

(Manes, 1983; Wolfson, 1983; Wolfson \& Manes, 1980)

These two sets of strategies were used in analyzing the structures of complaints and compliments which were found in the books, in order to determine the most frequent one(s).

\subsection{Data collection and procedure}

Through the study, the researcher applied a mixed-methods approach, incorporating both qualitative and quantitative approaches to achieve the purpose. The data was collected from the coursebooks directly. For the quantitative part of the study, the frequencies and also percentages of complaints and compliments to their total number were calculated in the listening exercises of all the four books which could be found in the last few pages of the books. A Chi-square test was also carried out in order to find whether there was any significant difference in the proportion of the speech acts. For the qualitative part on the other hand, the results were compared with the set of complaint strategies presented by Olshtain and Weinbach (1987), and the set of compliment structures presented by Wolfson and Manes (1981). The quality of the books was evaluated and analyzed considering the fore mentioned speech acts coverage in terms of frequency occurrences and strategy types.

\section{Results and Discussion}

The present study probed English Result coursebooks in terms of complaints and compliments' frequency of occurrences. All four books were investigated. With regard to complaints, the results of frequencies and percentages of each strategy are shown in Table 1.

In terms of frequency, the total number of complaints found was 95 . Of this total number, 19 belonged to E, 14 to PI, 33 to IN, and 29 to UI. The most frequent type of strategies in E was criticism, while this type was the least frequent one covered in PI, two only, both of which were about jobs. Examples of criticism in E included complaining about hotels. Some other examples include complaining to the agent about houses when looking for one to buy.

Expression of annoyance or disapproval was the most frequent in PI and UI. On the other hand, the common point in E, PI and UI regarding this strategy type was that they all included examples of boss-employee complaints - whether direct or indirect. In IN however, expression of annoyance or disapproval was the second most frequent strategy after others.

The most frequent strategies introduced in IN with a rather high frequency of 14, were of different types from those presented by Olshtain and Weinbach (1987). And there was also only one accusation and warning strategy type (in IN), and only one below the level of reproach type (in UI) found through all the four books. 
International Journal of Applied Linguistics \& English Literature

ISSN 2200-3592 (Print), ISSN 2200-3452 (Online)

Vol. 1 No. 6; November 2012

Table 1. Percentage and frequencies of complaints

\begin{tabular}{|c|c|c|c|c|c|c|c|c|}
\hline \multirow[t]{2}{*}{ Strategies } & \multicolumn{2}{|c|}{ Elementary } & \multicolumn{2}{|c|}{ Pre-intermediate } & \multicolumn{2}{|c|}{ Intermediate } & \multicolumn{2}{|c|}{ Upper-intermediate } \\
\hline & $\mathrm{N}$ & $\%$ & $\mathrm{~N}$ & $\%$ & $\mathrm{~N}$ & $\%$ & $\mathrm{~N}$ & $\%$ \\
\hline $\begin{array}{l}\text { (1) Expression } \\
\text { of annoyance } \\
\text { or disapproval }\end{array}$ & 5 & 5.26 & 12 & 12.63 & 7 & 7.36 & 15 & 15.78 \\
\hline $\begin{array}{l}\text { (2) Requests } \\
\text { for repair }\end{array}$ & 1 & 1.05 & 0 & 0 & 2 & 2.10 & 0 & 0 \\
\hline (3) Criticism & 13 & 13.68 & 2 & 2.10 & 6 & 6.31 & 11 & 11.57 \\
\hline $\begin{array}{l}\text { (4) Explicit } \\
\text { complaint }\end{array}$ & 0 & 0 & 0 & 0 & 3 & 3.15 & 0 & 0 \\
\hline $\begin{array}{l}(5) \\
\text { Accusation \& } \\
\text { warning }\end{array}$ & 0 & 0 & 0 & 0 & 1 & 1.05 & 0 & 0 \\
\hline $\begin{array}{l}\text { (6) Below the } \\
\text { level of } \\
\text { reproach }\end{array}$ & 0 & 0 & 0 & 0 & 0 & 0 & 1 & 1.05 \\
\hline (7) Others & 0 & 0 & 0 & 0 & 14 & 14.73 & 2 & 2.10 \\
\hline & 19 & 19.99 & 14 & 14.73 & 33 & 34.7 & 29 & 30.5 \\
\hline
\end{tabular}

Note: The percentages show the proportion of each strategy to the total number of complaint strategies

in the series.

The distributions of strategies display that strategies (1) and (3) dominate the field, since the frequency of occurrences for these strategies were much higher than those of other strategies within the books. It could be argued that in comparison to strategies (1) and (3), strategies (2), (4), (5), and (6) were totally ignored - having occurred only two or three times or in the case of (5) and (6), only once in sum. The implication could be that complaints are usually expressed with the statement of criticism, annoyance or disapproval, which may to some extent lead to the possibility that British people are rather conservative in performing this act, since there were only three explicit complaints through the four books. So, it allows us to conclude that there's a remarkable degree of 'face' consideration. As long as those strategies are more face-threatening - such as explicit complaint or requests for repair - than the others, this ignorance within the book may be attributed to try to save this social factor. However, there is the consequence that learners are exposed to a very limited range of complaint strategy structures, while they need to gain enough knowledge of them in order to be able to appropriately use them in different situations.Examples of each complaint strategy type found in the books are put into Table 2 .

Table 2. Examples of complaints strategies in the series

\begin{tabular}{|c|c|c|c|c|}
\hline & Elementary & Pre-intermediate & Intermediate & Upper-intermediate \\
\hline $\begin{array}{l}\text { (1) Expression of } \\
\text { annoyance or } \\
\text { disapproval }\end{array}$ & $\begin{array}{l}\text { - You always arrive } \\
\text { late! } \\
\text { - You're always at } \\
\text { the coffee table } \\
\text { with Holly. }\end{array}$ & $\begin{array}{l}\text { - It's awful in the } \\
\text { rain. } \\
\text { - What a pain! } \\
\text { - Also I hated the } \\
\text { long hours starting } \\
\text { at nine and } \\
\text { finishing at seven in } \\
\text { the evening. }\end{array}$ & $\begin{array}{l}\text { - He knocked on } \\
\text { your door for half } \\
\text { an hour. Knock } \\
\text { knock knock. What } \\
\text { a noise! I Couldn't } \\
\text { sleep. } \\
\text { - That horrible } \\
\text { woman in the next } \\
\text { flat came out and } \\
\text { shouted at me. I } \\
\text { was only knocking } \\
\text { on the door. } \\
\text { - It's terrible, isn't } \\
\text { it? }\end{array}$ & $\begin{array}{l}\text { - I think it's } \\
\text { disgusting... } \\
\text { - I hate it when you } \\
\text { have to waixt ages } \\
\text { for them to bring } \\
\text { the food. } \\
\text { - What a nerve! }\end{array}$ \\
\hline
\end{tabular}


International Journal of Applied Linguistics \& English Literature

ISSN 2200-3592 (Print), ISSN 2200-3452 (Online)

Vol. 1 No. 6; November 2012

\begin{tabular}{|c|c|c|c|c|}
\hline $\begin{array}{l}\text { (2) Requests for } \\
\text { repair }\end{array}$ & $\begin{array}{l}\text { - Explain that } \\
\text { please. }\end{array}$ & - & $\begin{array}{l}\text { - Please could you } \\
\text { tell your friends to } \\
\text { be quieter. } \\
\text { - I want you to try } \\
\text { harder. }\end{array}$ & - \\
\hline (3) Criticism & $\begin{array}{l}-\ldots \text { but the hotels } \\
\text { are too expensive. } \\
\text { - . . but they are } \\
\text { usually for one } \\
\text { week minimum. } \\
\text { - The breakfast's } \\
\text { too early. } \\
\text { - Too many spiders! }\end{array}$ & $\begin{array}{l}\text { - The worst thing } \\
\text { about the job is the } \\
\text { hours. I often have } \\
\text { to start work at four } \\
\text { in the morning. } \\
\text { - . . . but it's not } \\
\text { very well paid, and } \\
\text { the hours are quite } \\
\text { long. }\end{array}$ & $\begin{array}{l}\text { - We haven't been } \\
\text { selling many of } \\
\text { these sunshades } \\
\text { lately... } \\
\text { - When it's hot, } \\
\text { there's nothing you } \\
\text { can do about it. }\end{array}$ & $\begin{array}{l}\text { - . . . he's not } \\
\text { exactly committed } \\
\text { to his work you } \\
\text { know? } \\
\text { - I don't use blank } \\
\text { discs to make } \\
\text { illegal copies, so } \\
\text { why should I have } \\
\text { to pay the tax? }\end{array}$ \\
\hline $\begin{array}{l}\text { (4) Explicit } \\
\text { complaint }\end{array}$ & - & - & $\begin{array}{l}\text { - Aargh! I can't } \\
\text { stand it. You're too } \\
\text { NICE! } \\
\text { - I wish I was } \\
\text { somewhere far far } \\
\text { away from here. I } \\
\text { can't stand this } \\
\text { place! }\end{array}$ & - \\
\hline $\begin{array}{l}\text { (5) Accusation \& } \\
\text { warning }\end{array}$ & - & - & $\begin{array}{l}\text { Women! They're } \\
\text { absolutely awful } \\
\text { drivers. }\end{array}$ & - \\
\hline $\begin{array}{l}\text { (6) Below the level } \\
\text { of reproach }\end{array}$ & - & - & - & $\begin{array}{l}\text { - I wouldn't mind so } \\
\text { much but . . }\end{array}$ \\
\hline (7) Others & - & - & $\begin{array}{l}\text { - Mrs. Dickson } \\
\text { thinks the Lanes are } \\
\text { noisy and rough. } \\
\text { - I wish I didn't live } \\
\text { in a big city. } \\
\text { - She says the kids } \\
\text { are naughty. }\end{array}$ & $\begin{array}{l}\text { - The big artists and } \\
\text { record companies } \\
\text { get enough of our } \\
\text { money. I mean, } \\
\text { how many } \\
\text { swimming polls and } \\
\text { limousines do these } \\
\text { guys need? } \\
\text { - I wish he could } \\
\text { see that. }\end{array}$ \\
\hline
\end{tabular}

Regarding the length of the complaints, a slight increase was seen as the level of the books rose. There were more combinations of structures as the levels grew higher:

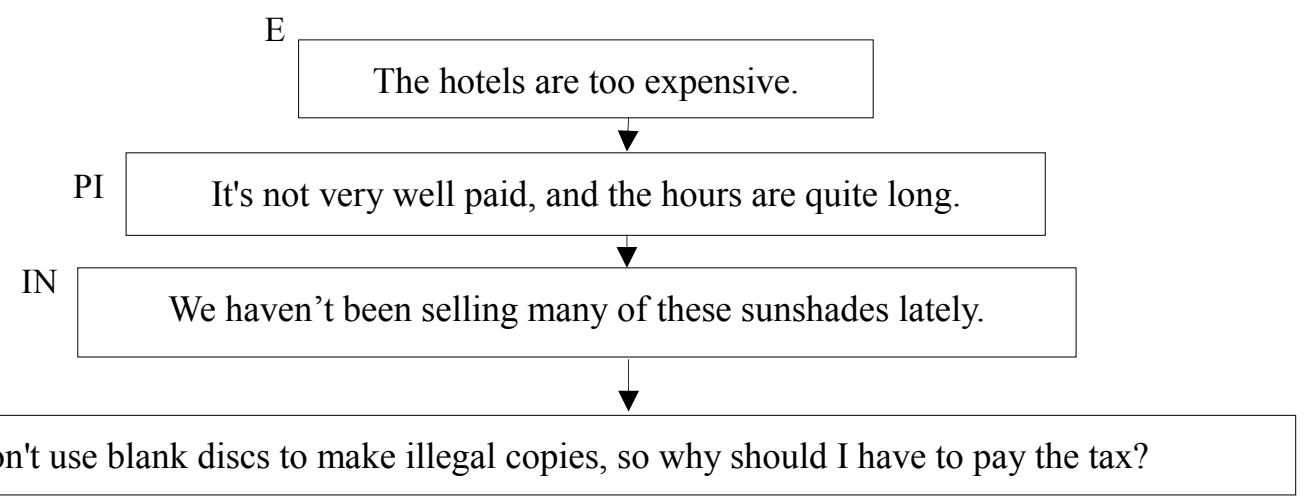

Figure 1. Length and degree of complexity in the criticism type of strategy in complaints 


\section{International Journal of Applied Linguistics \& English Literature}

ISSN 2200-3592 (Print), ISSN 2200-3452 (Online)

Vol. 1 No. 6; November 2012

It's worth mentioning that for E and PI levels mostly, the structures which were used to present complaints, appeared to depend to some extent on the grammar which was being taught in the associated page or unit.

Generally, disregarding the strategy types, the English Result Series were found out to be rich in terms of the number of complaints they covered (95), but the same is not true about their variety.

Results from compliment structures are displayed in Table 3. Regarding compliment strategies, there were a total number of 118 through all the four books, 13 of which belonged to E, 43 to PI, 33 to IN, and 29 to UI. The frequencies and proportions of each strategy type are shown in Table 3. The shaded areas display the most frequent strategy in each book. As can be seen, some certain structures presented by Wolfson and Manes (1981), introduced in section 3.1 were totally absent in the books (e.g. What (a) ADJ. NP!). The most frequent compliment structure in E, PI, and IN was 'NP (is/looks) (really) ADJ.' or 'PRO is (really) (a) ADJ.NP.' In UI, however, this structure was ranked as the second most frequent with a slight difference from the first one. Therefore, similar to complaints, in compliments there is also a focus of attention on one particular structure. In general, we may conclude that this structure is perhaps the most common one when performing compliments in British culture.

Disregarding zero frequencies, the least frequent structures in E were ' I (really) (like/love) NP.', ' ADJ. NP!', and also one more with a totally different structure from those mentioned in section 3.1 of this article, with the frequency of one for each type. For PI, the least frequent one was ' You V. NP. (really) ADV.', for I, it was ' You have (a) (really) ADJ. NP.' and 'ADJ. NP!', and for UI ' I (really) (like/love) NP.' and ' ADJ. NP!' were the two least frequent structures.

Table 3. Percentages and frequencies of compliments

\begin{tabular}{|l|c|c|c|c|c|c|c|c|}
\hline & \multicolumn{2}{|c|}{ Elementary } & \multicolumn{2}{c|}{ Pre-intermediate } & \multicolumn{2}{c|}{ Intermediate } & \multicolumn{2}{c|}{ Upper-intermediate } \\
\cline { 2 - 8 } & $\mathbf{N}$ & $\mathbf{0}$ & $\mathbf{N}$ & $\mathbf{\%}$ & $\mathbf{N}$ & $\mathbf{\%}$ & $\mathbf{N}$ & $\mathbf{2}$ \\
\hline $\begin{array}{l}\text { (1) NP (is/looks) } \\
\text { (really) ADJ. }\end{array}$ & $\mathbf{1 1}$ & 9.32 & $\mathbf{2 5}$ & 21.18 & $\mathbf{2 7}$ & 22.88 & $\mathbf{1 2}$ & 10.16 \\
$\begin{array}{l}\text { PRO is } \\
\text { (really) (a) } \\
\text { ADJ.NP. }\end{array}$ & & & & & & & & \\
\hline $\begin{array}{l}\text { (2) I (really) } \\
\text { (like/love) NP. }\end{array}$ & 1 & .84 & 4 & 3.38 & 0 & 0 & 2 & 1.69 \\
\hline $\begin{array}{l}\text { (3) You have } \\
\text { (a) (really) }\end{array}$ & 0 & 0 & 0 & 0 & 1 & .84 & 0 & 0 \\
ADJ. NP. & & & & & & & & \\
\hline (4) ADJ. NP! & 1 & .84 & 8 & 6.77 & 1 & .84 & 3 & 2.54 \\
\hline (6) others & 1 & .84 & 6 & 5.08 & 4 & 3.38 & $\mathbf{1 2}$ & 10.16 \\
\hline & 13 & 11.84 & 43 & 36.41 & 33 & 27.94 & 29 & 24.55 \\
\hline
\end{tabular}

Note: The percentages show the proportion of each strategy to the total number of complaint strategies in the series.

The same conclusion for complaints can be made for compliments as well. Although compliments are high in number, there is no certain pattern in their diversity all through the books.

Examples of each structure are put into Table 4.

Table 4. Examples of compliment structures in the series

\begin{tabular}{|c|c|c|c|c|}
\hline & Elementary & Pre-intermediate & Intermediate & Upper-intermediate \\
\hline $\begin{array}{l}(1) \\
-\quad \mathrm{NP} \text { (is/looks) } \\
\text { (really) ADJ. } \\
\text { - PRO is (really) (a) } \\
\text { ADJ.NP. }\end{array}$ & $\begin{array}{l}\text { - These biscuits are } \\
\text { delicious. } \\
\text { - The toilet's always } \\
\text { clean! }\end{array}$ & $\begin{array}{l}-. . . \text { he's very } \\
\text { attractive. } \\
-\ldots \text { and it's } \\
\text { really beautiful. }\end{array}$ & $\begin{array}{l}\text { - Well, it's a good } \\
\text { question. } \\
\text { - That's great. }\end{array}$ & $\begin{array}{l}\text { - That's a good } \\
\text { book, isn't it? } \\
\text { - . . . the starting } \\
\text { time's great. }\end{array}$ \\
\hline
\end{tabular}


International Journal of Applied Linguistics \& English Literature

ISSN 2200-3592 (Print), ISSN 2200-3452 (Online)

Vol. 1 No. 6; November 2012

\begin{tabular}{|l|l|l|l|l|}
\hline $\begin{array}{l}\text { (2) I (really) } \\
\text { (like/love) NP. }\end{array}$ & I love your books. & $\begin{array}{l}\text { - I love this blue } \\
\text { color. } \\
\text { - I like this scarf. }\end{array}$ & \multicolumn{1}{|c|}{ - quite enjoy the } \\
adverts.
\end{tabular}

A Chi-square was run in order to find whether there is any significant difference between the proportions of the two speech acts in the books. Firstly, the frequency occurrences of complaints and compliments were compared to each other in each book. The four output tables of SPSS were integrated into one table (Table 5).

As can be seen from the table, in E and PI, there was a significant difference at the level of .05 with d.f. $=1$. For IN and UI on the other hand, no significant difference was reported. This is due to the equal number of complaint and compliment strategies in these books.

Table 5. A comparison between the proportion of compliment and complaint strategies

\begin{tabular}{|c|c|c|c|c|c|c|c|c|c|c|c|}
\hline \multicolumn{2}{|l|}{ Strategy } & \multicolumn{2}{|c|}{$\mathrm{E}$} & & \multicolumn{2}{|c|}{ PI } & \multirow[b]{2}{*}{ Total } & \multirow{2}{*}{\begin{tabular}{|l} 
IN \\
33
\end{tabular}} & \multirow{2}{*}{ Total } & \multirow{2}{*}{\begin{tabular}{|c|} 
UI \\
29
\end{tabular}} & \multirow[b]{2}{*}{ Total } \\
\hline & & 13 & 19 & Total & 14 & 43 & & & & & \\
\hline \multirow[t]{3}{*}{ Complaint } & Count & 0 & 1 & 1 & & 0 & 1 & 1 & 1 & 1 & 1 \\
\hline & $\begin{array}{l}\text { \% within } \\
\text { strategy }\end{array}$ & $\begin{array}{l}.0 \\
\%\end{array}$ & $\begin{array}{l}100.0 \\
\%\end{array}$ & $\begin{array}{l}100.0 \\
\%\end{array}$ & $\begin{array}{l}100.0 \\
\%\end{array}$ & $.0 \%$ & $\begin{array}{l}100.0 \\
\%\end{array}$ & $\begin{array}{l}100.0 \\
\%\end{array}$ & $\begin{array}{l}100.0 \\
\%\end{array}$ & $\begin{array}{l}100.0 \\
\%\end{array}$ & $\begin{array}{l}100.0 \\
\%\end{array}$ \\
\hline & $\begin{array}{l}\text { Std. } \\
\text { Residual }\end{array}$ & $\begin{array}{l}-.7 \\
*\end{array}$ & $.7 *$ & & $.7 *$ & $-.7 *$ & & .0 & & .0 & \\
\hline \multirow[t]{3}{*}{ Compliment } & Count & 1 & 0 & 1 & 0 & 1 & 1 & 1 & 1 & 1 & 1 \\
\hline & $\begin{array}{l}\text { \% within } \\
\text { strategy }\end{array}$ & $\begin{array}{l}10 \\
0.0 \\
\%\end{array}$ & $.0 \%$ & $\begin{array}{l}100.0 \\
\%\end{array}$ & $.0 \%$ & $\begin{array}{l}100.0 \\
\%\end{array}$ & $\begin{array}{l}100.0 \\
\%\end{array}$ & $\begin{array}{l}100.0 \\
\%\end{array}$ & $\begin{array}{l}100.0 \\
\%\end{array}$ & $\begin{array}{l}100.0 \\
\%\end{array}$ & $\begin{array}{l}100.0 \\
\%\end{array}$ \\
\hline & $\begin{array}{l}\text { Std. } \\
\text { Residual }\end{array}$ & $.7 *$ & $-.7 *$ & & $-.7 *$ & $.7 *$ & & .0 & & .0 & \\
\hline \multirow[t]{2}{*}{ Total } & Count & 1 & 1 & 2 & 1 & 1 & 2 & 2 & 2 & 2 & 2 \\
\hline & $\begin{array}{l}\text { \% within } \\
\text { strategy }\end{array}$ & $\begin{array}{l}50 . \\
0 \\
\%\end{array}$ & $\begin{array}{l}50.0 \\
\%\end{array}$ & $\begin{array}{l}100.0 \\
\%\end{array}$ & $\begin{array}{l}50.0 \\
\%\end{array}$ & $\begin{array}{l}50.0 \\
\%\end{array}$ & $\begin{array}{l}100.0 \\
\%\end{array}$ & $\begin{array}{l}100.0 \\
\%\end{array}$ & $\begin{array}{l}100.0 \\
\%\end{array}$ & $\begin{array}{l}100.0 \\
\%\end{array}$ & $\begin{array}{l}100.0 \\
\%\end{array}$ \\
\hline
\end{tabular}

Note: asterisks show significance $(\mathrm{p}<.05$, for $\mathrm{E}$ and PI $)$.

Regarding the total proportion of complaint and compliment strategies, Chi-square made the results given in Table 8. It was proved that despite the IN and UI levels of the books not revealing any significant difference, complaint and compliment strategies were significantly different at the level of .05 in terms of their proportion. This indicates that, although in IN and UI, the frequencies of the two speech act strategies were equal, the books did not follow the same pattern in presenting them. 
International Journal of Applied Linguistics \& English Literature

ISSN 2200-3592 (Print), ISSN 2200-3452 (Online)

Vol. 1 No. 6; November 2012

Table 8. A comparison between the total number of complaint and compliment strategies

\begin{tabular}{|c|c|c|c|c|c|}
\hline & & & \multicolumn{2}{|c|}{ Sum } & \multirow[b]{2}{*}{ Total } \\
\hline & & & 95 & 118 & \\
\hline \multirow[t]{6}{*}{ Strategy } & 0 & Count & 1 & 0 & 1 \\
\hline & & $\%$ within strategy & $100.0 \%$ & $.0 \%$ & $100.0 \%$ \\
\hline & & Std. Residual & $.7 *$ & $-.7 *$ & \\
\hline & 1 & Count & 0 & 1 & 1 \\
\hline & & $\%$ within strategy & $.0 \%$ & $100.0 \%$ & $100.0 \%$ \\
\hline & & Std. Residual & $-.7 *$ & $.7 *$ & \\
\hline \multirow[t]{2}{*}{ Total } & & Count & 1 & 1 & 2 \\
\hline & & $\%$ within strategy & $50.0 \%$ & $50.0 \%$ & $100.0 \%$ \\
\hline
\end{tabular}

( $0=$ complaint, $1=$ compliment $)$

Note: the asterisks show significance $(\mathrm{p}<.05)$.

The results are in line with part of the findings from Delen and Tavil (2010) who demonstrated that there was a bias to some particular speech act strategies in Summit, Top Notch and Northstar Reading and Writing Series.

According to the study done by Delen and Tavil (2010), who investigated three sets of course books, Summit, Top Notch and Northstar Reading and Writing, it was reported that there was almost no complaint strategy found through the three course book series. While in the present work, it was documented that the course books were highly quantified in terms of providing learners with complaint and compliment strategies; however, in terms of quality and diversity in the range of those speech acts, they operated rather weakly.

\section{Conclusion and Implications}

This study first investigated the frequency of two types of speech acts, complaints and compliments in English Result course books (RQ 1). In general terms, the books turned out to present complaints and compliments adequately regarding frequencies. But in terms of strategy types for each speech act specifically, attention was largely on only one or two particular structures, while totally ignoring others. In other words, some strategies were dominant (such as expression of annoyance or disapproval and criticism in complaints, and ' NP (is/looks) (really) ADJ.' structure in compliments) among the other ones.

The second point of this study (RQ 2) had to do with proportions of the two speech acts and that whether or not there was a statistically significant difference between their proportions through all the four levels of the series (E, PI, IN, and UI). Findings from Chi-square analysis revealed that for the first two levels of the series, E and PI, there actually was a significant difference, but the same claim was not proved for the last two levels, IN and UI. This is due to the fact that, surprisingly, the frequencies of complaints and compliments in these two books were exactly the same! But the point is that despite this fact, Chi-square also showed significance in the total proportion of the speech acts.

The present study contributes useful implications for the teachers who are interested in teaching their learners speech acts. It supports the need for teachers not to limit themselves in the framework of the course books, incorporating appropriate teaching of speech acts in the classroom, allocating more time to them, and focusing on different types of speech act strategies according to the learners' needs, and suitability of classroom context and activities.

The study may be helpful to the writers of the studied course books, to evaluate their books more deeply in terms of complaints and compliments strategies, in order to gain a more cohesive and comprehensive framework in this regard, and provide their audience with adequate and appropriate materials they need to learn and apply in real life in order to make successful communication. 


\section{References}

Ang-Abbey, L. (1991). Transfer behavior of Hokkien Chinese speakers in apologizing. Borneo Research Bulletin, 23, 14-35.

Austin, J. L. (1962). How to do things with words. New York: Oxford University Press.

Azizifar, A. Koosha, M. , \& Lotfi, A. R. (2010). An analytical evaluation of Iranian high school ELT textbooks from 1970 to the present. Procedia Social and Behavioral Sciences, 3, 36-44.

Bachman, L. (1990). Fundamental considerations in language testing. Oxford University Press: Oxford.

Blum-Kulka, Sh. (1987). Indirectness and politeness in requests: same or different?. Journal of Pragmatics, 11 (2), 131-146.

Bouton, L. F. (1996). Pragmatics and language learning. In L. Bouton (Ed.), Pragmatics and Language Learning, Monograph 7 (pp. 1-20). Urbana-Champaign, IL: University of Illinois Division of English as an International Language.

Boxer, D. (1993). Complaints as positive strategies: What the learner needs to know. TESOL Quarterly, 27 (2), 277-299.

Brown, P., \& Levinson, S. (1987). Politeness: Some universals in language usage. Cambridge: Cambridge University Press.

Canale, M., \& Swain, M. (1980). Theoretical bases of communicative approaches to second language teaching and testing. Applied Linguistics, 1 (1), 1-47.

Chen, Sh. E. (2003). Compliment Response Strategies in Mandarin Chinese: Politeness Phenomenon Revisited. Concentric: Studies in English Literature and Linguistics, 29 (2), 157-184.

Cordella, M. (1990). Apologizing in Chilean Spanish and Australian English: a cross-cultural perspective. Australian Review of Applied Linguistics Series, 7, 66-92.

Cordella, M. (1991). Spanish speakers apologizing in English: a cross-cultural pragmatics study. Australian Review of Applied Linguistics, 14 (2), 115-138.

Delen, B., \& TAvil, Z. M. (2010). Evaluation of four coursebooks in terms of three speech acts: Requests, refusals and complaints, Procedia Social and Behavioral Sciences, 9, 692-697.

Garcia, C. (1989). Apologizing in English: politeness strategies used by native and non-native speakers. Multilingua, 8 (1), 3-20.

Hancock, M., \& McDonald, A. (2009). English Result Elementary. Oxford: Oxford University Press.

Hancock, M., \& McDonald, A. (2009). English Result Pre-intermediate. Oxford: Oxford University Press.

Hancock, M., \& McDonald, A. (2009). English Result Intermediate. Oxford: Oxford University Press.

Hancock, M., \& McDonald, A. (2009). English Result Upper-intermediate. Oxford: Oxford University Press.

House, J., \& Kasper, G. (1981). Politeness markers in English and German. In: F. Coulmas (Ed.), Conversational Routine (pp. 157-186). The Hague: Mouton.

Jebahi, Kh. (2011). Tunisian university students' choice of apology strategies in a discourse completion task, Journal of Pragmatics 43, 648-662.

Kim, H.J. A study of compliments across cultures: The effect of sociolinguistic trasnfer of EFL learners, Korea: Korea University.

Lipson, M. (1994). Apologizing in Italian and English. International Review of Applied Linguistics, 32 (1), 19-39.

Manes, J. (1983). Compliments: A mirror of cultural values. In N. Wolfson \& E. Judd (Eds.), Sociolinguistics and language acquisition (pp. 96-102). Rowley, MA: Newbury House.

Manes, J., \& Wolfson, N. (1981). The compliment formula. Conversational Routine, ed. by F. Coulmas (pp. 115-132). The Hague: Mouton.

Marti, L. (2006) Indirectness and politeness in Turkish-German bilingual and Turkish monolingual requests, Journal of Pragmatics, 38, 1836-1869. 
International Journal of Applied Linguistics \& English Literature

ISSN 2200-3592 (Print), ISSN 2200-3452 (Online)

Vol. 1 No. 6; November 2012

Meier, Ardith J. (1995). Passages of politeness. Journal of Pragmatics, 24, 381-392.

Meier, Ardith J. (1996). Two cultures mirrored in repair work. Multilingua, 15 (2), 149-169.

Meier, Ardith J. (1997). Teaching the universals of politeness. ELT Journal, 51, 21-28.

Olshtain, E. (1989). Apologies across languages. In: Blum-Kulka, Sh., House, J., \& Kasper, G. (Eds.),

Cross-cultural pragmatics: Requests and apologies, advances in discourse processes (pp. 155-173). Ablex:

Norwood.

O’Neill, R. (1982). Why use textbooks? ELT Journal, 36( 2), 104-111.

Salazar Campillo, P. (2007). Examining Mitigation in Requests: A Focus on Transcripts in ELT Coursebooks. In E. Alcón Soler, \& M. P. Safont (Eds.), Intercultural Language Use and Language Learning (pp. 207-222). The

Netherlands: Springer.

Stadler, S. A. (2011). Coding speech acts for their degree of explicitness, Journal of Pragmatics, 43, 36-50.

Suszczynska, M. (1999). Apologizing in English, Polish and Hungarian: different languages, different strategies. Journal of Pragmatics, 31, 1053-1065.

Usó-Juan, E. (2007). The presentation and practice of the communicative act of requesting in textbooks:

Focusing on modifiers. In E. Alcón Soler, \& M. P. Safont (Eds.), Intercultural Language Use and Language Learning (pp. 223-243). The Netherlands: Springer.

Vellenga, H. 2004. Learning pragmatics from ESL \& ESL textbooks: How likely? TESLEJ, 8 (2). Retrieved May 15, 2010 from http://www.teslej. org/wordpress/issues/volume8/ej30/ej30a3/

Weizman, E. (1989). Requestive hints. In S. Blum-Kulka, J. House, G. Kasper (Eds.), Cross-Cultural Pragmatics (pp. 71-96). Ablex: Norwood.

Wierzbicka, A. (1985). Different cultures, different languages, different speech acts: Polish vs. English. Journal of Pragmatics 9, 145-178.

Wierzbicka, A. (1991). Cross-cultural pragmatics: The semantics of human interaction. Berlin: Mouton de Gruyter.

Wolfson, N. (1983). An empirically based analysis of complimenting behavior in American English. In N.

Wolfson \& E. Judd (Eds.), Sociolinguistics and language acquisition (pp. 82-95). Rowley, MA: Newbury House.

Wolfson, N., \& Manes, J. (1980). Compliment as social strategy. International Journal of Human

Communication, 13, 391-410.

Wouk, F. (2006). The language of apologizing in Lombok, Indonesia, Journal of Pragmatics. 38, 1457-1486.

Yasemin, K. (2009). Evaluating the English textbooks for young learners of English at Turkish primary education. Procedia Social and Behavioral Sciences, 1, 79-83.

Zarei, Gh. R. (2011). Functional analysis of Iranian learners' L2: Complimenting in written discourse. International Journal of Language Studies (IJLS), 5(2), 109-122. 